\title{
A COMPARISON OF THE ANTERIOR HORN CELLS IN THE NORMAL SPINAL CORD AND AFTER AMPUTATION *
}

\author{
A. E. TAFT, M.D.
}

Formerly Curator, Department of Neuropathology, Harvard Medical School; Assistant Physician, Pennsylvania Hospital for Nervous and Mental Diseases

PHILADELPHIA

This work arose from the negative results of an examination, by a student in the department of neuropathology, of three spinal cords from cases having had amputation of a limb sometime previous to death. The findings were so little in accord with the idea of postamputation pathology gained from various textbooks, that a further examination of cords was undertaken in the same manner, from subjects not showing signs of cord lesions during life, and from that point of view called normal. Except for this general precaution material was chosen at random.

A variety of findings are recorded in the literature as a result of investigations of the changes in the anterior horn cells following amputation. No attempt has been made to include a complete literary review; the plan is only to give an idea of the varied results arrived at by a number of experienced investigators.

\section{LITERATURE}

Campbell ${ }^{1}$ says, after considerable work on this subject, "it may be explained that in consequence of such a lesion alterations occur in the spinal cord and these in course of time occasion striking and characteristic appearances. In long-standing cases the predominant change is a homolateral atrophy, represented by a general reduction in volume of white and gray matter alike, and involving those particular segments of the cord which receive and give off the sensory and motor nerves which originally supplied the skin and muscles of the amputated member. Wasting of the gray substance is accompanied by the numerical reduction of its contained nerve cells, both large and small, and while

* Contribution in a series offered to Professor E. E. Southard in honor of the decennium of the Bullard Professorship of Neuropathology, Harvard Medical School.

1. Campbell, A. W.: Changes in the Spinal Cord Following Amputation, British M. J., March 14, 1896, p. 663; Post-Amputation Change in the Cerebral Cortex, Histological Studies on Localization of Cerebral Function, p. 47. 
all the cell collections in the anterior cornu suffer, one special group may be singled out as being specially prone to atrophy, namely, the posterolateral."

Marinesco, ${ }^{2}$ one of the earlier investigators of this question, is one very often quoted. His report includes three cases: one with duration of twenty-one years; one ten years, and the third of unknown duration. He found changes in anterior horn cells; in the first two cases a reduction in number on the side of the amputation, not only in the lateral, but in other groups; in the third case neither the cell count in the posterolateral group, nor of all cells in all groups have sufficient significance to conclude that there is any definite change in the cells.

Edinger ${ }^{3}$ reports a case of prenatal amputation of the left lower arm with death at 52 years of age. The left side of the cord corresponding to the four lower cervical and first two dorsal segments showed a distinct atrophy of the anterior horn, which was greatest at the level of the sixth and seventh cervical segments. There was also a distinct decrease in the size and number of the anterior horn cells, especially at the anterolateral and posterolateral angles of the anterior horn. In three additional cases of postamputation, no convincing proof of cell atrophy was found in the anterior horns.

Van Gehuchten ${ }^{4}$ examined the lumbosacral cord from a case twelve years after amputation of the lower extremity in the middle portion of the thigh. The anterior horn cells representing the foot muscles were normal, while the cells representing the muscles below the knee had disappeared, in spite of the fact that the axons of both groups of cells had been divided.

Déjerine and Mayer $^{5}$ studied eight cases of amputation varying from four to forty years following amputation. They found in all cases a definite decrease in the size of the side of the cord corresponding to the amputation, affecting both white and gray matter, both anterior and posterior. In only one case were histologic changes found; this was following amputation of the thigh, of thirty years' duration. In the middle of the lumbar enlargement a definite decrease in the number of anterior horn cells appeared, the number being only a third of the normal side, and the anteromesial group was the one most affected.

2. Marinesco, G.: Ueber Veränderungen der Nerven und des Rückenmarks nach Amputationen; ein Beitrag zur Nerventrophik, Neurol. Centralbl. 11:463, 1892.

3. Edinger, L.: Rückenmark und Gehirn in einem Falle von angeborenem Mangel eines Vorderarms, Virchow's Archiv. 89:46, 1882.

4. Van Gehuchten: Handbuch der Anatomie des Nervensystems, 1:139; Bull. de l'Acad. roy. de Belgique, 1898, p. 222; Presse méd. Jan. 4, 1899.

5. Déjerine and Mayer: Bull. Soc. de Biol., 1878. 
Elders, ${ }^{6}$ in an excellent article, reports the examination of the cord of a person born without the left lower arm. Death occurred at 54 years of age. In the lower half of the left cervical segment the posterolateral angle was rounder and shorter than the right and contained fewer cells.

Dreschfeld ${ }^{7}$ examined a case of amputation of the left thigh fifteen years after operation, and found atrophy of the anterior horn and some change in the posterior horn in the lower part of the left lumbar enlargement, with decrease in number and atrophy of the nerve cells of the intermediolateral group.

Kahler and Pick ${ }^{8}$ report two cases, one of which was an amputation of the lower third of the left thigh, eighteen years after operation. The anterior horn cells were decreased in the anterior group. The second case was an amputation of the left forearm in the lower third. He reports partial atrophy and decrease in the number of cells in the lateral group.

Dickinson $^{9}$ reports findings on a case of amputation of the right leg fifteen years before death, in which there was a decrease in the number and size of the nerve cells of the corresponding side.

Genzmer ${ }^{10}$ found decrease in size of anterior horn and in the number of anterior horn cells on the amputated side in a case of amputation of the lower third of the right thigh 30 years before death.

Hayem $^{11}$ examined the cord in the case of exarticulation of the wrist, five years after operation, and found general atrophy of the anterior horn with atrophy of nerve cells, most marked at the level of the eighth cervical and first dorsal nerves.

Friedreich' $\mathrm{s}^{12}$ case of amputation of the left forearm twelve years before death showed no changes in the cord; the anterior horn cells were intact.

\section{ANIMAL EXPERIMENT}

Experimental work also has been done on various laboratory animals, both by section of nerve trunks and by amputation of extremities.

6. Elders: Monatsch. f. Psychiat. u. Neurol., 1910.

7. Dreschfeld: On the Changes in the Spinal Cord After Amputation of Limbs, J. Anat. \& Physiol. 14:424, 1879.

8. Kahler and Pick: Weitere Beiträge zur Pathologie und Pathologischem Anatomie der Central Nervensystems, Arch. f. Psychiat. 10:360.

9. Dickinson: On the Changes Which Occur in the Spinal Cord After Amputation of a Limb, Compared with the Changes Found in Progressive Muscular Atrophy, Trans. of Path. Soc. of London, 24: 1873.

10. Genzmer: Veränderungen im Rückenmark eines Amputierten, Virchow's Archiv. 66:265, 1876 .

11. Hayem: Arch. de Physiol. Norm. et Path., T. V., 1873, p. 504.

12. Friedreich: Ueber Progressive Muskelatrophie, Berlin, 1873. 
Van Gehuchten ${ }^{4}$ divided the sciatic nerve and later found only the cells of the posterolateral group affected.

Homén's ${ }^{13}$ work on animals showed a slight atrophy and decrease in the number of cells of the anterior horn. The individual cells were found in general somewhat smaller than the corresponding ones on the opposite side. No changes were found in the brain.

The experimental work of Warrington ${ }^{14}$ is a more recent and detailed investigation of the changes of the anterior horn cells after section of the spinal nerve roots. In some instances changes were found both in anterior and posterior horn cells corresponding to the side operated on. He reports finding changes not only on the corresponding side, but also on the opposite side. "After section of several posterior roots from the VIth to the IXth post thoracic inclusive, a considerable percentage of obviously altered cells are found. Their distribution in the case of the cat is practically limited to the VIIth and VIIIth segments, and especially to the postero-lateral group of cells in those segments. In the monkey the upper part of the VIIth segment is picked out. The effect is to a very slight extent a crossed one and presents the remarkable feature that more affected cells were found in the VIth segment of the crossed side than on the side of the lesion." Further, "the view I wish to maintain is that the changes are the result of the withdrawal of the afferent impulses which normally impinge on cornual cells. Histological evidence shows that the posteroexternal group of anterior horn cells is most richly innervated by the collaterals from the posterior roots." He thus explains the degeneration of this group of cells, and adds further with emphasis that the changes occurring after section of the posterior roots are much more intense and that the ultimate destruction of these cells is more likely to occur than after the division of the anterior roots alone. After section of both anterior and posterior roots all the larger cells on the side of the lesion showed changes. The greater number were only slightly affected compared to the extent seen after section of an anterior nerve root alone; others, however, showed a much more marked chromatolysis, the changes resembling those found after section of the afferent roots. He finally concludes that there is a tendency for the altered cells to return to their normal structure regardless of the regeneration of their axons, in conformity with the opinions of Van Gehuchten and Nissl. ${ }^{15}$

13. Homén: Veränderungen des Nervensystems nach Amputationen in Ziegler: Beiträge zur Pathologischen Anatomie, 1890, p. 304.

14. Warrington: Observations on the Structural Alterations Observed in Nerve Cells, J. Physiol. 23: 1898.

15. Niss1, F.: München. med. Wchnschr., 1898, p. 6. 
FROM TEXTBOOKS

Concerning the change in the anterior horn cells following division of their fibers Oppenheim" says: "The Nissl stain shows destruction of the granules and an excentric position of the nucleus. If a restitution in the periphery takes place, regeneration results. If, however, there is no peripheral regeneration, further change in the form of atrophy takes place in the cells."

Van Gehuchten: The section of the axon leads to a rapid swelling of the cell protoplasm, and consequent displacement of the nucleus. He believes that in a small number of cases the swelling of the cell body takes place so rapidly and the force which pushes the nucleus to one side is so powerful that it is driven completely out of the cell body. These cells are the only ones, he concludes, which completely atrophy, while all the others slowly return to normal.

Déjerine and Thomas: ${ }^{17}$ For localization studies, division of nerves has been made. In man, the cords of persons having had amputations have been studied with the same end in view, but the application of this method has not always been free from reproach.

Schäfer: If the degeneration has been caused by section of the axon, the reparative process is very slow, so that it may be three or four months before it is completed. At the end of this time the nerve-cell bodies have resumed their original appearance even though reparation of the cut nerve may be incomplete.

Barker $:^{18}$ The motor fibers of the central stump gradually diminish in number; in some instances they appear to vanish almost totally, and a large number of the motor cells of the ventral horns dwindle in size and after a time actually may be lost.

\section{MATERIAL EXAMINED}

The tissue was prepared in serial paraffin sections, 6 microns thick, and stained by the cresylechtviolet cell-stain method.

Material from three cases of amputation was examined as a starting point of this work, and mainly from the point of view of loss of anterior horn cells. Sections were examined from the segments of the cord corresponding to the part amputated, and the cells of both anterior horns were counted.

CASE 1.-Man, aged 79, sixty years after amputation of left arm. The anterior horn cells showed no chromatolysis, but many of the cells were well filled with lipochrome. This is not unusual in view of the age of the man. One hundred and thirty-three serial sections were counted. The variation in individual sections was considerable, but the final average of all counts was, right 17 , left 19 , or an average of two cells more on the amputated than on the opposite side.

In the brain the Betz cells and other large elements contained much lipochrome, but showed no reaction to the amputation.

CASE 2.-Man, aged 65 years, recent amputation of lower third of the left leg. The anterior horn cells were very little altered. There was no chromat-

16. Oppenheim, H.: Lehrbuch der Nervenkrankheiten, 1:148.

17. Déjerine and Thomas: La Moelle Epiniere, 165.

18. Barker, L. F.: The Nervous System, New York, p. 230. 
olysis, and very little lipochrome. Forty-one serial sections were counted. Variation in individual sections was as much as $62: 38$ between the two sides. The average of the total number counted was, right 52 , left 55 , or an average of three more cells on the amputated side. As the operation in this case was performed only the day before death (following gangrene of the foot), no permanent change in nerve cells would be expected. No axonal change had taken place.

CASE 3.-Female, aged 73, old amputation of right thigh. The anterior horn cells contained a great deal of lipochrome, but also some normal Nissl granules. A total of 41 counts was made on serial sections. The variation in individual sections was as great as $13: 32$. The total average was, right, 21.8; left, 23.9, or an average of two more cells on the nonamputated than on the amputated side.

In addition to these counts others were made on material from a variety of cases, with the single precaution that they show no clinical signs of cord involvement. Both sexes were included, and the ages ranged from 11 months to 71 years.

One case considered particularly suitable for use as a normal control was that of a young male adult, 37 years of age. Here the average of 67 counts in the cervical region was 50 on one side and 54 on the other; of 53 counts in the dorsal region, 12.0 on one side and 12.9 on the other; in the lumbar region the average of 62 counts was 49.5 on one side and 52.0 on the other. This variation is seen to be greater than in the cases of amputation. In Marinesco's ${ }^{2}$ work the greatest number of sections of one level counted is sixteen, and the variation in the sum total is $245: 223$. In the instances where a smaller number of sections were counted, the difference between the two sides was even greater. In the case of the normal control just described, in one group of 21 counts, the total was 938 on one side and 1,181 on the other; but in the final sum of all counts, 67 in all, the number was 2,603 on one side and 2,684 on the other.

In the accompanying table the detail of the entire number of cases counted may be seen. No attempt was made to identify the exact segment of the cord from which the blocks were taken, as much of the material was already embedded without regard to this detail; consequently, there is a great difference in the count at the varying levels. It may be noted also that numbers are much larger up to and including Case 26 than in the subsequent ones. This is due to the fact that in the earlier cases all cells were counted which represented the full contour of a cell including any of its processes, exclusive of whether it contained a nucleus or not. Later, only those cells were counted which contained a stained nucleus. But since the comparison is that of the two sides of the cord, and not between different specimens, the relation is not altered. 
TABle 1.-Counts of Anterior Horn Cells in Serial Sections of SPINAL CoRd

\begin{tabular}{|c|c|c|c|c|c|c|c|c|c|c|}
\hline \multirow{3}{*}{ Case } & \multirow{3}{*}{ Diagnosis } & \multirow{3}{*}{ Sex } & \multirow{3}{*}{ Age } & \multicolumn{7}{|c|}{ Following Amputation } \\
\hline & & & & \multicolumn{2}{|c|}{ Cervical } & \multicolumn{2}{|c|}{ Dorsal } & \multicolumn{2}{|c|}{ Lumbar } & \multirow{2}{*}{$\begin{array}{l}\text { Sections } \\
\text { Counted }\end{array}$} \\
\hline & & & & 1 & 2 & 1 & 2 & 1 & 2 & \\
\hline \multirow{4}{*}{$\begin{array}{l}1 \\
2 \\
3\end{array}$} & \multirow{4}{*}{$\begin{array}{l}\text { Amputation, left arm....... } \\
\text { Amputation, left leg........ } \\
\text { Amputation, right leg...... }\end{array}$} & \multirow{4}{*}{$\frac{\mathbf{M}}{\mathbf{M}}$} & \multirow{4}{*}{$\begin{array}{l}79 \\
65 \\
73\end{array}$} & 19.3 & 17.4 & $\ldots$ & $\ldots$ & & & \multirow{3}{*}{$\begin{array}{r}133 \\
41 \\
41\end{array}$} \\
\hline & & & & $\ldots$. & $\ldots$ & $\ldots$ & $\ldots$ & 55 & 52 & \\
\hline & & & & $\ldots$ & $\ldots$ & $\ldots$ & $\ldots$ & 23.9 & 21.8 & \\
\hline & & & & \multicolumn{7}{|c|}{ Without Amputation } \\
\hline 4 & Congenital syphilis.. & $\mathbf{F}$ & 13 & 15 & $\overline{16}$ & 6 & 5.7 & I6.- & 17.8 & C.15-D.17-L.18 \\
\hline 5 & Not insane........... & $\mathbf{M}$ & 6 & 14.- & 18.6 & 4.9 & 5.- & 18.-* & 15.- & 0.15-D.15-L.16 \\
\hline 6 & Organic dementia.......... & $\overrightarrow{\mathbf{M}}$ & 42 & 23.- & 31.8 & $5.5^{*}$ & 6.- & 37.5 & 28.- & C.16-D.14-T.15 \\
\hline 7 & Mongolian jdiot............. & $\mathbf{F}$ & 6 & 11.8 & $12,-$ & 11.6 & 14.- & $28.8^{*}$ & 27.- & 0.15-D.26-L.26 \\
\hline 8 & Idiot........ & $\mathbf{M}$ & 17 & 43.- & 52.7 & 10.7 & 10.8 & 29.4 & 31.- & C.18-D.22- $\mathrm{L} .19$ \\
\hline 9 & Imbecile........ & $\mathbf{F}$ & 46 & $36,-$ & 32.- & 6.- & 6.- & 34.- & 31.- & $0.18-0.17-L .15$ \\
\hline 10 & Alcoholic............. & $\mathbf{F}$ & 38 & $30.7^{*}$ & 28.- & 6.-* & 6.- & 33..* & 37.- & C.16-D.17-L.15 \\
\hline 11 & Auto-intoxication.... & $\mathbf{F}$ & 42 & $29 .-*$ & $34 .-$ & 7.-* & 6.- & $33.7^{*}$ & $35 .-$ & 0.16-D.34-L.18 \\
\hline 12 & Alcoholic delirium.... & $\mathrm{F}$ & 32 & $27.6^{*}$ & 41.6 & $6.8^{*}$ & 7.- & 27.- & 28.6 & 0.15-D.33-L.18 \\
\hline 13 & Special control......... & $\mathbf{M}$ & 37 & 50.4 & 54.3 & 12.- & 12.9 & 49.5 & 52.4 & C.67-D.53-L.62 \\
\hline 14 & Presenile depression... & $\mathbf{F}$ & 68 & $23.5^{*}$ & 22.5 & 4.-* & 5.- & $19.9^{*}$ & 17.9 & C.15-D.15-L.15 \\
\hline 15 & Unclassifled.......... & $\mathbf{M}$ & 71 & 19.4 & 19.6 & 2.8 & 3.8 & 19.- & 17.8 & C.15-D.15-L.15 \\
\hline 16 & Delirium..... & $\mathrm{F}$ & & 14.9 & 13.4 & 2.6 & 2.5 & 17.8 & 19.2 & $0.15-\mathrm{D} .36-\mathrm{L} .15$ \\
\hline 17 & Not jnsane.. & $\mathbf{F}$ & 51 & & $\ldots$ & 8.- & 8.6 & 22.7 & 21.8 & D.34-L.14 \\
\hline 18 & Dementia praecox... & $\mathbf{F}$ & 40 & $21 .{ }^{*}$ & $25 .-$ & $5.9^{*}$ & 5.4 & 14. -* & 11.- & C.21-D.18-L.22 \\
\hline 19 & Imbecile............. & $\mathbf{M}$ & 34 & $34.3^{*}$ & 21.3 & $11.3^{*}$ & 6.3 & $24.9^{*}$ & 23.4 & 0.20-D.25-L. 20 \\
\hline 20 & General paresis... & $\mathbf{M}$ & 39 & $20.4^{*}$ & 20.2 & 3.- $*$ & 3.1 & $8.2^{*}$ & 8.5 & C. $20-\mathrm{D} .20^{\circ}-\mathrm{L} .20$ \\
\hline 21 & Unclassifled... & $\bar{M}$ & 21 & & & 4.- & 4.- & 14. -* & 13.5 & D.41-L.25 \\
\hline 22 & ohronic dementia... & $\mathbf{F}$ & 40 & $\ddot{8} .9^{*}$ & $\ddot{8.1}$ & $1.8^{*}$ & 3.- & 11.-** & 9.1 & C.31-D.21-L.33 \\
\hline 23 & Puerperal mania...... & $\mathbf{F}$ & 24 & $6.6^{*}$ & 7.8 & $2.1^{*}$ & 2.- & $7.4^{*}$ & 8.7 & C.21-D.22-L. .20 \\
\hline 24 & Uremic intoxication........ & $\bar{F}$ & 28 & 4. $-^{*}$ & 5.6 & $1.3^{*}$ & 1.9 & $7.7^{*}$ & 6.6 & C.23-D.32- $\mathbf{L} .21$ \\
\hline 25 & Dementia praecox.... & $\mathbf{F}$ & 35 & $6.5^{*}$ & 6.9 & $1.2^{*}$ & 1.2 & $10.3^{*}$ & 10.4 & $0.20-\mathrm{D} .22-\mathrm{L} .20$ \\
\hline 26 & Imbecile..... & $\mathbf{M}$ & 36 & $5.5^{*}$ & 3.4 & $2.1^{*}$ & 2.2 & $\ldots$ & & C.16-D.17 \\
\hline 27 & (Infant).... & $\cdots$ & $11 \mathrm{mo}$ & $6.9^{*}$ & 6.2 & $3 . .^{*}$ & 3.8 & 13. $-^{*}$ & 12.6 & C.23-D.22-L.22 \\
\hline 28 & Unclassifled.... & $\mathbf{F}$ & $\begin{array}{l}3 \mathrm{yr} . \\
\end{array}$ & & $\ldots$ & & 2.7 & 17. -* & 19.- & D.24-1.24 \\
\hline
\end{tabular}

* Left side of cord.

These results contribute something also to the question of whether the number of cells is greater on one side or the other from the standpoint of right and left handedness. It will be seen that there is no constant relation throughout the list, the number being greater as an average on one side in some instances, and less on the same side in another, with very slight variation in any case, and no more in the cervical than in the lumbar region. By means of a low power lens, it may be seen in progressing from one section to another that one horn contains the greater number of cells, first on one side and then on the other, and the same variation is seen in the individual cell groups.

It may be noted here that Bruce ${ }^{19}$ found only the fifth cord specimen examined suitable for use in preparing his Atlas of the Spinal Cord.

\section{SUMMARY}

Cell counts were made on the anterior horns of the spinal cord in twenty-eight cases. Three of these were cases following amputation of an extremity. The twenty-five additional cases were said not to have had signs of a cord lesion.

19. Bruce, A.: Atlas of the Spinal Cord, 1901, p. 3. 
Variations in the counts between the two sides in the amputated cases was not more than two or three cells in the final average. In two of these the greater number was on the side corresponding to the amputation.

Variations in the counts between the two sides in the cases without amputation was at times greater than with amputation.

In the sections where identification was made of the right and left sides, there appears no uniform difference between the two corresponding counts.

\section{CONCLUSIONS}

The literature contains a variety of opinions concerning the permanent changes in the anterior horn cells of the spinal cord following amputation.

A fairly large number of counts of anterior horn cells of the spinal cord from cases without amputation show as great a variation in the number of cells as in cases with amputation.

In the material examined there seems to be no constant variation between the number of anterior horn cells in the right and left sides of the spinal cord. 